\title{
Estudi de la contaminació atmosfèrica de la plana del Camp de Tarragona (Catalunya) prenent els líquens com a bioindicadors
}

\author{
MIREIA GIRALT
}

\begin{abstract}
Resumen
Giralt, M. (1997). Estudio de la contaminación atmosférica de la llanura del Campo de Tarragona (Catalunya) tomando los líquenes como bioindicadores. Collect. Bot. (Barcelona) 23: 53-71.

Se evalua la contaminación atmosférica de la llanura litoral del Camp de Tarragona (Cataluña) tomando como bioindicadores los líquens epífitos del algarrobo (Ceratonia siliqua). Se caracterizan ochenta y cinco estaciones según diversos parámetros: índice de pureza atmosférica (IPA), recubrimiento medio global (RMG) y nombre de especies. La combinación de los datos obtenidos permite dividir el área estudiada en seis zonas de isocontaminación. Por otra parte, se clasifican 15 especies de líquenes y el alga Pleurococcus en función de su resistencia a la contaminación atmosférica.
\end{abstract}

Palabras clave: Líquenes, Contaminación Atmosférica, Bioindicadores.

\section{Résumé}

GiRalt, M. (1997). Étude de la pollution atmosphérique de la plaine du Camp de Tarragona (Catalogne) en utilisant les lichens comme bioindicateurs. Collect. Bot. (Barcelona) 23: 53-71.

La pollution atmosphérique d'une partie du littoral méditerranéen Catalan (Camp de Tarragona, Catalogne, Espagne) a été estimée en utilisant les lichens épiphytes corticoles du caroubier (Ceratonia siliqua) comme bioindicateurs. Quatre-vingt cinc stations on été étudiées et characterisées par le calcul de divers paramètres. En combinant les données fournies par l'Index de Pureté de l'Air (IPA), le recouvrement moyen global (RMG) et le nombre d'espèces, l'aire étudiée est divisée en six zones d'isopollution. Par ailleurs, 15 espèces de lichens et une algue (Pleurococcus) sont classées en fonction de leur résistance a la pollution atmosphérique.

Mots clé: Lichens, Pollution Atmosphérique, Bioindicateurs.

\section{INTRODUCCIÓ}

Segons BRIGHTMAN (1982) la sensibilitat dels líquens envers la contaminació atmosfèrica fou intuïda ja per Erasmus Darwin (1731-1802) en observar el comportament dels líquens pròxims a les mines de coure d'Anglessey (Anglaterra). Però és NYLANDER (1866), en definitiva, el primer que proposa la utilització d'aquests organismes com a indicadors de la qualitat de l'aire, segons observacions fetes als Jardins de Luxembourg

Mireia Giralt. Departament de Biologia Vegetal (Botànica). Facultat de Biologia. Universitat de Barcelona. Diagonal 645. E-08028 Barcelona. 
(París). A partir de llavors, i fins ara, nombrosos treballs realitzats arreu del món demostren, mitjançant diverses metodologies, que els líquens són extremadament sensibles a la contaminació atmosfèrica.

L'estudi per avaluar la contaminació atmosfèrica de la ciutat de Tarragona i dels seus polígons industrials, mitjançant els líquens epifítics, ja va ser realitzat els anys 1984-1985 (GIRALT, 1986 i GiRALT et al., 1989). L'àrea estudiada, però, ocupava només la plana del Tarragonès, de manera que els efectes contaminants d'altres nuclis urbans (Reus, Valls) i industrials (Constantí, el Morell, la Pobla de Mafumet) no foren estimats.

L'estudi que presentem aquí completa aquell treball, afegint a la zona ja estudiada $\left(125 \mathrm{~km}^{2}\right)$, la resta de la plana del Camp de Tarragona $\left(1000 \mathrm{~km}^{2}\right)$, de manera que permet conèixer, no solament la distribució espacial de la contaminació atmosfèrica a la totalitat de la plana del Camp de Tarragona (distribució que no pot ésser coneguda mitjançant els enregistradors existents de fums i $\mathrm{SO}_{2}$, ja que només se situen a les zones urbanes i industrials) sinó també quines espècies liquèniques existents a la zona són les que mostren un millor valor indicador.

\section{Característiques de la zona estudiada}

La plana del Camp de Tarragona constitueix una unitat física. Està envoltada de muntanyes, té una superfície aproximada de $1000 \mathrm{~km}^{2}$, reposa sobre formacions miocèniques i quaternàries, se situa entre els $0 \mathrm{i}$ els $350 \mathrm{~m}$ sobre el nivell del mar i inclou les conques mitjanes i baixes dels rius Gaià i Francolí. El seu clima és típicament mediterrani, amb hiverns suaus i estius calorosos. Els vents dominants són el mestral (NW) i la marinada (SE). Els sòls són d'escassa potència i pertanyen al domini de la terra bruna meridional, excepte el nivell de les terrasses fluvials.

La vegetació superior de les terres incultes està constituïda per brolles del RosmarinoEricion Br.-Bl., 1931, més o menys arbrades amb pi blanc. A les terres conreades hi trobem bàsicament garrofer. L'avellaner domina als marges dels rius Gaià i Francolí, l'olivera substitueix progressivament el garrofer cap a l'oest i la vinya domina al $\mathrm{N}$ i NE.

La vegetació liquènica és formada per l'associació Dirinetum ceratoniae Klement, 1965 (KLEMENT, 1965) i per l'associació Lecanoro hybocarpae-Caloplacetum pollinii Llimona et al. (GIRALT, 1994). La primera es troba plenament desenvolupada a la façana litoral per sota dels $100 \mathrm{~m}$. Comença a empobrir-se a altituds superiors i desapareix per sobre dels $200 \mathrm{~m}$ i a una distància aproximada de $10 \mathrm{~km}$ de la costa. El seu límit varia d'una zona a l'altra de la plana. A ponent, desapareix ja a $7 \mathrm{~km}$ de la costa, a causa possiblement a la influència negativa del mestral. A llevant, suporta $10 \mathrm{~km}$ de distància al mar i, a les planes de Valls i Reus, on la la plana s'endinsa seguint la vall del riu Francolí, hom pot observar-la encara a $20 \mathrm{~km}$ de la costa. L'associació Lecanoro hybocarpaeCaloplacetum pollinii es troba més o menys ben representada arreu del territori, però les espècies que la integren, menys termòfiles que les de la comunitat anterior, assoleixen el seu màxim desenvolupament a les localitats més allunyades de la costa i per sobre dels 200 m. A la costa, en canvi, tant per les condicions climàtiques menys favorables (massa tèrmiques), com per la competència de les espècies del Dirinetum ceratoniae, no es troba tan ben representada. El nombre d'espècies és en general més elevat al Dirinetum ceratoniae ja que incorpora algunes espècies del Lecanoro hybocarpae-Caloplacetum pollinii. Entre el domini del Dirinetum ceratoniae i el del Lecanoro hybocarpae-Caloplacetum pollinii hi trobem una zona de "transició" on ambdues comunitats conviuen. En aquesta zona, tant el nombre d'espècies com la suma dels seus recobriments, augmenten respecte als de la resta de l'area estudiada.

Els focus contaminants principals a l'àrea són les ciutats de Tarragona, Valls i Reus i els polígons industrials de Tarragona (Torreforta, la Canonja, Bonavista, Vila-seca) i del 
Francolí (Constantí, la Pobla de Mafumet i el Morell). Els contaminants més importants en aquestes zones són el $\mathrm{SO}_{2}$ i els fums.

Les dades dels contaminants atmosfèrics s'han obtingut de 23 enregistradors manuals existents, 8 situats a la ciutat de Tarragona, 3 a la de Valls, 4 a la Reus, 2 als polígons compresos entre Tarragona i Vila-seca i 6 als polígons del Francolí, situats entre Tarragona i Valls. La mitjana anual és de $23,13 \mu \mathrm{g} / \mathrm{m}^{3}$ de $\mathrm{SO}_{2}$ i $22,3 \mu \mathrm{g} / \mathrm{m}^{3}$ de fums, a la ciutat de Tarragona; $18 \mu \mathrm{g} / \mathrm{m}^{3}$ de $\mathrm{SO}_{2}$ i $94 \mu \mathrm{g} / \mathrm{m}^{3}$ de fums, a la ciutat de Valls; $5,8 \mu \mathrm{g} / \mathrm{m}^{3}$ de $\mathrm{SO}_{2}$ i $18,8 \mu \mathrm{g} / \mathrm{m}^{3}$ de fums, a la ciutat de Reus i $8,25 \mu \mathrm{g} / \mathrm{m}^{3} \mathrm{SO}_{2}$ i $8 \mu \mathrm{g} / \mathrm{m}^{3}$ de fums, a les zones industrials de Tarragona i del Francolí. Aquestes dades han estat facilitades pel Servei de Protecció de l'Ambient Atmosfèric de la Direcció General de Medi Ambient de la Generalitat de Catalunya. Les dades obtingudes a la mateixa zona, a partir d'enregistradors automàtics, indiquen continguts de $\mathrm{SO}_{2}$ i fums més elevats que les dades obtingudes amb els enregistradors manuals. Per tant, considerem que aquestes dades són poc fiables, i per aquest motiu, no fem un buidatge més complet.

\section{METODOLOGIA}

Diversos mètodes han estat descrits per avaluar la contaminació atmosfèrica a partir dels líquens epifítics (VAN HALUWYN \& LEROND, 1986). Entre ells, el mètode de HAWKSWORTH \& ROSE (1970), basat en la identificació d'espècies sensibles no podia ésser aplicat, ja que aquestes espècies, de caràcter boreo-atlàntic, són absents o excepcionals a l'àrea estudiada. En canvi, s'ha pogut aplicar el mètode de l'índex de puresa atmosfèrica o IPA (LeBlanc \& DE Sloover, 1970), basat en criteris quantitatius i no qualitatius. A més dels criteris bàsics exigits per aquest mètode, hem tingut en compte altres caràcters de la vegetació liquènica que varien amb la contaminació (nombre d'espècies, recobriment $\mathrm{i}$ riquesa florística).

\section{Recollida de les dades}

El foròfit. Per tal de reduir al màxim les variables ecològiques susceptibles d'afectar el desenvolupament dels líquens, els mostreigs s'han fet sempre sobre el mateix arbre, el garrofer (Ceratonia siliqua). Aquest és l'arbre de conreu més ben representat a l'àrea estudiadat, fet que facilita l'estandarització de les estacions mostrejades ja que permet escollir grups d'arbres que creixen pròxims. Per altra banda, a diferència dels altres arbres conreats a la zona (avellaner, olivera i ametller), no reb cap tractament fito-sanitari que pugui afectar la seva vegetació epifítica.

Les estacions. S'han seleccionat 85 estacions, numerades de l'1 al 85, uniformement repartides per tot el territori estudiat, intentant que l'únic factor ecològic variable entre elles fos la contaminació atmosfèrica, de manera que les diferències observades d'una estació a l'altra en el nombre d'espècies, el recobriment o la vitalitat, no fossin el resultat d'altres factors ecològics, com ara el clima, la topografia, etc.

De les estacions seleccionades, 75 es troben al domini del Dirinetum ceratoniae i i les 10 restants al del Lecanoro hybocarpae-Caloplacetum pollinii.

Per tal de no introduir altres factors aliens a la contaminació atmosfèrica els índexs han estat calculats dues vegades. Un primer càlcul agrupa la totalitat de les estacions (85) i l'hem anomenat IPAT, mentre que el segon exclou les 10 estacions situades fora del domini del Dirinetum ceratoniae i l'hem anomenat IPA2.

Aquestes estacions són les següents: E37, E39, E41 i E42, situades al NE de la ciutat 
de Tarragona, i E70, E71, E72, E74, E75 i E76, situades a l'oest de la mateixa ciutat. L'IPA2 s'ajusta més a les condicions que exigeix l'aplicació d'aquest mètode quantitatiu que l'IPAT, ja que les condicions ecològiques de les 75 estacions a partir de les quals es calcula són homogènies.Així, per definir les zones d'isocontaminació hem tingut en compte l'IPA2. Es remarca que l'àrea situada al nord de la ciutat de Valls no ha pogut ser mostrejada, ja que gran part de la seva superfície es destina al conreu de la vinya.

Anomenem estació (E) a un conjunt de garrofers pròxims. Cada estació es numera per identificarla (x) i s'anoten el nombre de garrofers estudiats (A). A cadascuna de les 85 estacions seleccionades hem mostrejat entre 5 i 10 garrofers.

Inventaris: Sobre cada garrofer es realitza un inventari de la vegetació liquènica seguint la metodologia proposada per CRESPO \& al. (1981), i aplicada ja a GIRALT (1986), que permet elaborar la llista d'espècies presents a cada tronc, entre 120 i $160 \mathrm{~cm}$ del sòl, $\mathrm{i}$ determinar-ne el coeficient de recobriment $(R)$ per a cada espècie observada.

Paràmetres ecològics: En cada estació (Ex), cada espècie (s) es caracteritza pel seu recobriment total $(\mathrm{Rt})$, definit per la suma dels recobriments $\mathrm{R}$ que presenta l'espècie $(\mathrm{s})$ sobre cadascún dels arbres $(\mathrm{A})$ de l'estació $(\mathrm{Ex}), \mathrm{Rt}=\sum \mathrm{A}(\mathrm{s}) \mathrm{R}$. Pel seu recobriment mitjà $(\mathrm{Rm})$, equivalent a la relació entre el $\mathrm{Rt}(\mathrm{s})$ i el nombre d'arbres (A) de l'estació, $\mathrm{Rm}=$ $\mathrm{Rt}(\mathrm{s})$ / A. Per la seva presència (P), que és igual al nombre d'arbres de l'estació que presenten l'espècie. Per la seva presència mitjana $(\mathrm{Pm})$, igual a la relació entre la $\mathrm{P}(\mathrm{s}) \mathrm{i}$ el nombre d'arbres $(A)$ de l'estació, $\mathrm{Pm}=\mathrm{P}(\mathrm{s}) / \mathrm{A}$. Per la seva freqüència $(\mathrm{F})$, definida per la suma del recobriment mitjà i de la presència mitjana dividida per dos, $F=(R m+P m) / 2$. En la regió, cada espècie es caracteritza per la presència total (PT o P2), que és igual al nombre d'estacions que presenten l'espècie. L'índex ecològic (QT o Q2), equival a la mitjana del nombre d'espècies que acompanyen una espècie determinada, $\mathrm{Q}=\sum \mathrm{E}(\mathrm{s}) \mathrm{n}-1$ / $\mathrm{E}(\mathrm{s})$. Aquests dos darrers paràmetres són anomenats PT i QT quan l'índex que es calcula és l'IPAT (inclou les 85 estacions seleccionades) i P2 i Q2 quan l'índex que es calcula és l'IPA2 (s'exclouen les 10 estacions situades en el domini de l'associació Lecanoro hybocarpae-Caloplacetum pollinii).

El paràmetres que caracteritzen les estacions es defineixen pel nombre d'espècies (n) de l'estació. Per la riquesa florística (D), que és igual al quocient entre el nombre d'espècies de l'estació i el nombre d'espècies de l'estació més rica en espècies. Pel recobriment mitjà global (RMG), que és la suma dels recobriments mitjans de cadascuna de les n espècies presents a l'estació (Ex), RMG $=\sum \mathrm{n}(\mathrm{Ex}) \mathrm{Rm}$. Per l'índex de puresa atmosfèrica (IPA) es calcula a partir de l'índex ecològic (Q) i de la freqüència $F$ de cadascuna de les espècies presents a l'estació (Ex), segons la formula:

$$
\text { IPA }=1 / 10 \sum n(E x)(Q . F)
$$

Quan l'índex és calculat a partir de QT, és a dir tenint en compte les dades de les 85 estacions, és anomenat IPAT i quan és calculat a partir de Q2, és a dir tenint en compte les dades de 75 estacions (al domini del Dirinetum ceratoniae), és anomenat IPA2.

Les zones d'isocontaminació venen determinades pel nombre $\mathrm{N}$ d'estacions de la zona. Pels intervals de RMG i per l'interval de l'IPA, definits respectivament pels valors més baixos i el més alts de les estacions de la zona. Per la mitjana del nombre d'espècies (Xs), que és igual al quocient entre la suma del nombre d'espècies de cadascuna de les $\mathrm{N}$ estacions d'una zona i el nombre d'estacions $\mathrm{N}$ de la zona.

$$
\mathrm{Xs}=\sum \mathrm{n}(\mathrm{Ex}) / \mathrm{N}
$$

I per la mitjana de la riquesa florística (XD) de la zona, que és igual al quocient entre la suma de les riqueses florístiques de cadascuna de les $\mathrm{N}$ estacions de la zona i el nombre d'estacions $\mathrm{N}$ de la zona,

$$
\mathrm{XD}=\Sigma \mathrm{D}(\mathrm{Ex}) / \mathrm{N}
$$


Les dades i paràmetres relatius a les espècies i a la vegetació liquènica de cadascuna de les 85 estacions seleccionades estan agrupades en 85 taules a GIRALT (1991). Les dades i paràmetres relatius al total d'espècies i d'estacions, estan agrupades a la taula 3. Les estacions (en abscisses) estan caracteritzades pel seu nombre (Ex), pel nombre d'arbres (A), pel nombre d'espècies (n) i per la riquesa florística (D), a la part alta de la taula, i pel recobriment mitjà global (RMG) i els índexs de puresa atmosfèrica (IPAT i IPA2), a la part baixa de la taula. Les espècies (en ordenades) estan caracteritzades per la presència total (PT i P2) i per l'índex ecològic (QT i Q2). A la intersecció hi figura la frequència $(\mathrm{F})$ de l'espècie a l'estació. Aquest coeficient és una expressió sintètica del recobriment mitjà $(\mathrm{Rm})$ i de la presència mitjana $(\mathrm{Pm})$ de l'espècie a l'estació.

Es van determinar les zones d'isocontaminació tot agrupant les estacions en classes. Els diversos procediments utilitzats (DERUElle, 1983; DeRUElle \& GarCIA-ShaEfFer, 1983; GiRALT et al., 1989) agrupen en una mateixa zona les estacions que presenten un valor d'IPA pròxim. El nombre de zones a representar és completament arbitari. La majoria d'autors distingeixen 5 zones al voltant dels nuclis contaminants, tant urbans com industrials, però rarament en justifiquen els seus límits. La millor manera d'establir les zones és mitjançant intervals de l'IPA de la mateixa amplitud (GRANGER, 1972; GIRALT et al., 1989). Altres autors proposen zones de la mateixa superfície (CASE, 1980) o les defineixen en funció dels caràcters ecològics de la vegetació liquènica determinats empíricament (CRESPO et al., 1977).

En aquest treball seguim a GRANGER (op. cit.), però hem tingut en compte intervals d'igual amplitud no només pels valors de l'IPA, sino també pels valors del RMG. Les diferents amplituds d'intervals assajades pel nombre d'espècies i per la riquesa florística no proporcionen resultats coherents.

Per tal de determinar el grau de sensibilitat de les espècies a la contaminació de manera quantitativa només s'han considerat les espècies presents en més de 20 estacions. Els paràmetres utilitzats, per agrupar les espècies en distintes classes de sensibilitat, han estat: l'índex ecològic $(\mathrm{Q} 2)$, la presència total $(\mathrm{P} 2)$ i la repartició, és a dir, la presència/absència de l'espècie en cada zona d'isocontaminació.

\section{RESULTATS}

Sobre els garrofers de les 85 estacions de l'àrea estudiada s'han censat 41 espècies de líquens (30 crustàcies, 10 foliàcies i 1 fruticulosa) i una d'algues. L'ordenació de les dades a la taula 3 segueix els criteris exposats a GIRALT et al., (1989): les estacions s'ordenaren de dreta a esquerra, segons els valors de l'IPA (IPAT i IPA2) creixent i, les espècies, de dalt a baix, d'acord amb valors decreixents de P (PT i P2).

Per definir les zones d'isocontaminació s'han escollit intervals d'amplitud 4 de l'IPA i d'amplitud 3 del RMG. Procedint d'aquesta manera l'àrea estudiada queda subdividida en sis zones d'isocontaminació, numerades de I a VI (fig. 1) i caracteritzades pels valors de l'índex de puresa atmosfèrica (IPA), el recobriment mitjà global (RMG), la mitjana de la riquesa florística (XD) i la mitjana del nombre d'espècies (XS)

Les diferents amplituds d'intervals assajades pels paràmetres nombre d'espècies i riquesa florística no conserven les estacions de les zones III, IV i V agrupades. El nombre mitjà d'espècies i riquesa florística mitjana per zona indiquen, en canvi, que per terme mitjà existeix un increment d'ambdós paràmetres en passar d'una zona a l'altra. Els sensors situats a les zones I (ciutats de Tarragona i Valls) i II (polígons industrials i ciutat de Reus), indiquen que la primera presenta una mitjana de $20,6 \mu \mathrm{g} / \mathrm{m}^{3}$ de $\mathrm{SO}_{2}$ i $58,15 \mu \mathrm{g} / \mathrm{m}^{3}$ de fums i la segona de $7 \mu \mathrm{g} / \mathrm{m}^{3}$ de $\mathrm{SO}_{2}$ i $13,4 \mu \mathrm{g} / \mathrm{m}^{3}$ de fums. No existeixen sensors a la resta de zones. Les 
zones d'isocontaminació i les estacions que les defineixen s'observen en el mapa de la figura 1. Dues estacions E56 i E26, se situen pels dos intervals escollits (IPA i RMG) a cavall entre dues zones. E56, entre les zones II i III i E26, entre les zones III i IV.

Classes de sensibilitat de les espècies

Entre les 42 espècies trobades, només 15 (14 líquens i l'alga Pleurococcus) mostren pautes clares de variació quantitativa com a resposta a la contaminació atmosfèrica. Aquestes espècies poden ser distribuïdes en cinc grups segons, la presència total (P2), l'índex ecològic $(\mathrm{Q} 2)$ i la repartició o presència/absència a les diferents zones d'isocontaminació (taula 2).

Classe S1: $69 \leq \mathrm{P} 2 \leq 73 ; 12,7 \leq \mathrm{Q} 2 \leq 13,1$; presents a totes les estacions, sense evitar les més contaminades. Espècies molt resistents: Dirina ceratoniae, Pleurococcus sp., Bactrospora patellarioides i Schismatomma picconianum.

Classe S2: $66 \leq \mathrm{P} 2 \leq 70 ; 13,3 \leq \mathrm{Q} 2 \leq 13,6$; normalment presents a les zones II a VI. Absents de la zona I. Espècies bastant resistents: Hyperphyscia adglutinata, Xanthoria parietina i Lecanora horiza.

Classe S3: $44 \leq \mathrm{P} 2 \leq 51 ; 14,4 \leq \mathrm{Q} 2 \leq 15$; absents de la zona I i II o com a màxim presents en un 50\% d'estacions de la zona II. Presents normalment a les zones III a VI. Espècies moderadament resistents: Phaeophyscia hirsuta, Arthonia melanophthalma, Lecanora hybocarpa, Porina aenea i Thelopsis isiaca.

Classe S4: $34 \leq \mathrm{P} 2 \leq 41$; Q2= 16; absents de les zones I, II i d'un 50\% d'estacions de la zona III. Presents normalment a les zones IV-VI. Espècies sensibles: Schismatomma decolorans i Lecidella elaeochroma.

\begin{tabular}{|lllcc|}
\hline \multicolumn{2}{|c}{ IPA2 } & RMG & XD & Xs \\
\hline ZONA I & $1,78-3,37$ & $1,40-2,88$ & 13,0 & 2,6 \\
ZONA II & $4,95-7,99$ & $4,14-6,20$ & 41,2 & 9,5 \\
ZONA III & $9,43-11,85$ & $7,80-9,30$ & 56,7 & 13,1 \\
ZONA IV & $13,26-15,15$ & $10,80-12,63$ & 69,8 & 16,0 \\
ZONA V & $16,56-19,89$ & $13,30-16,40$ & 77,1 & 17,5 \\
ZONA VI & $22,36-25,80$ & $17,06-19,30$ & 95,0 & 21,8 \\
\hline
\end{tabular}

Taula 1.- Intervals dels paràmetres IPA2 i RMG i mitjanes dels paràmetres D i N que caracteritzen les sis zones d'isocontaminació a la plana del Camp de Tarragona.

Classe S5: P2= 21; $16,8 \leq \mathrm{Q} 2 \leq 17,4$; absents de les zones I, II, d'un 90\% d'estacions de la zona III i d'un 50\% d'estacions de la zona IV. Presents normalment a les zones V i VI. Espècies molt sensibles: Pertusaria heterochroa i Physcia gr. tenella.

\section{DISCUSSIÓ}

La taula 3 mostra una crisi progressiva de la vegetació liquènica epifítica de la dreta (estacions allunyades de les zones industrials i urbanes) vers l'esquerra (estacions situades a les zones industrials i urbanes). Aquesta crisi, deguda a la contaminació atmosfèrica, és tant qualitativa (algunes espècies desapareixen) com quantitativa (els paràmetres presència i recobriment, sintetitzats en el valor $\mathrm{F}$, són més elevats, en la majoria 
d'espècies, a les zones no contaminades que a les zones contaminades).

La sensibilitat de la vegetació liquènica és especialment interessant, ja que es tracta d'una zona mitjanament contaminada (segons les dades existents de $\mathrm{SO}_{2}$ i de fums) i d'una vegetació essencialment formada per líquens crustacis, considerats per diversos autors més resistents que els líquens foliacis i fruticulosos. Això confirma, tal i com diuen DeRUELLE \& LALLEMENT (1983), que la sèrie "poleotolerant" (= toxicotolerant) establerta per diversos autors en relació amb la forma biològica crustacis-foliacis-fruticulosos no es retroba sempre $\mathrm{i}$, per tant, no pot ésser generalitzada.

La taula 3 mostra també que les espècies presents a la zona més contaminada són les mateixes que manifesten presències i recobriments més elevats a les zones no contaminades. Aquestes pertanyen al Dirinetum ceratoniae, l'associació millor representada al territori i, per tant, són espècies ecològicament ben adaptades. Es constata també que les espècies de l'associació Lecanoro hybocarpae-Caloplacetum pollinii, menys adaptades a la zona costanera, són més sensibles (desapareixen abans) que les del Dirinetum ceratoniae.

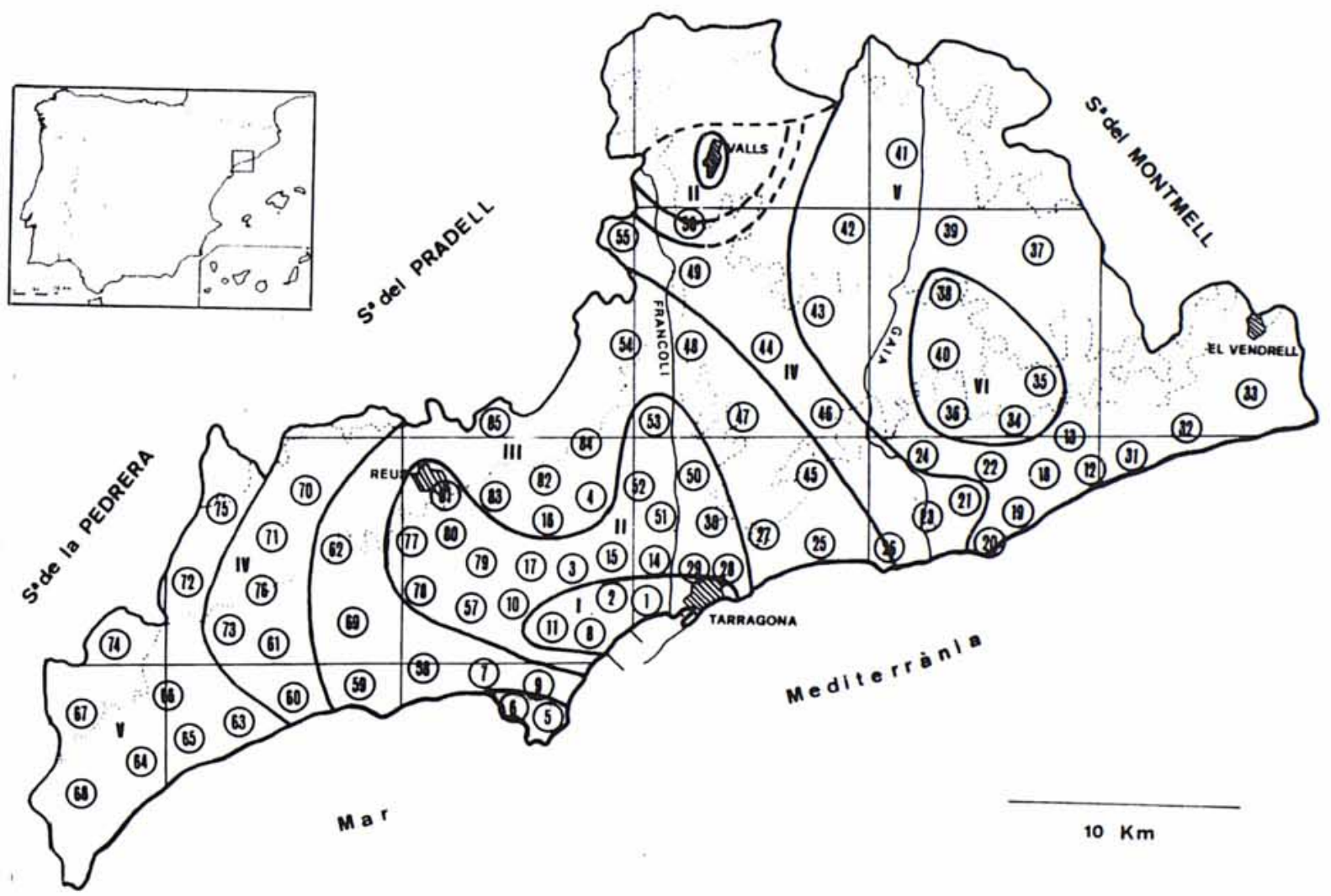

Fig. 3.- Mapa del Camp de Tarragona on es localitzen les 85 estacions estudiades (números d' 1 a 85 ) i les sis zones d'isocontaminació.

Per altra banda, en estacions sotmeses a la influència de la contaminació (zones II i III), però situades a la zona de "transició", on les espècies del Dirinetum ceratoniae cohabiten amb les Lecanoro-Caloplacetum, s'observa que les espècies del Dirinetum esdevenen més sensibles, mentre que les del Lecanoro-Caloplacetum esdevenen més resistents. Així, per exemple, tant Lecanora hybocarpa com Lecidella elaeochroma, que no apareixen fins a la zona III, les trobem ja a l'estació E56, situada a la zona de "transició" i amb valors de l'IPA intermedis entre els de les zones II i III. Cal destacar també que la majoria d'estacions de la zona III que presenten Lecidella elaeochroma, estan situades a la zona de 
"transició". Això suggereix que una espècie es comporta com a més resistent a la contaminació quan es troba millor adaptada ecològicament.

Exactament les mateixes estacions queden incloses a cadascuna de les sis zones d'isocontaminació definides tenint en compte els intervals d'amplitud 4 de l'IPA i 3 del RMG, excepte les 10 estacions més brutes de la zona IV, que són separades tant d'aquesta zona com de la zona precedent (III) per l'interval escollit del RMG. Segons aquest paràmetre, aquestes 10 estacions podrien constituïr una zona intermèdia entre les zones III i IV. Això es correspon amb la situació de les estacions, ja que són, entre la resta d'estacions de la zona IV, les més pròximes físicament a la zona III.

Les diferents amplituds d'intervals assajades en els paràmetres nombre d'espècies i riquesa florística no conserven les estacions de les zones III, IV i V agrupades. Concretament, per cadascuna d'aquestes zones, les estacions amb menys espècies $\mathrm{i}$ amb un nombre més elevat d'espècies respecte del nombre mitjà d'espècies de la zona, s'incorporen a la zona precedent i següent, respectivament. Aquesta manca de coherència és deguda al fet que les estacions amb menys espècies d'aquestes zones presenten recobriments més elevats respecte de la zona precedent i les que presenten més espècies,

\begin{tabular}{|c|c|c|c|c|}
\hline Classe & P2 & Q2 & Repartició & Espècies \\
\hline S1 & $\begin{array}{l}73 \\
72 \\
69 \\
71\end{array}$ & $\begin{array}{l}12,7 \\
12,7 \\
12,9 \\
13,1\end{array}$ & $\begin{array}{l}\text { I, II, III } \\
\text { IV, V, VI }\end{array}$ & $\begin{array}{l}\text { Dirina ceratoniae } \\
\text { Pleurococcus } \\
\text { Bactrospora patellarioides } \\
\text { Schismatomma picconianum }\end{array}$ \\
\hline S2 & $\begin{array}{l}70 \\
70 \\
66\end{array}$ & $\begin{array}{l}13,3 \\
13,4 \\
13,6\end{array}$ & $\begin{array}{l}\text { II, III, IV } \\
\text { V, VI }\end{array}$ & $\begin{array}{l}\text { Hyperphyscia adglutinata } \\
\text { Xanthoria parietina } \\
\text { Lecanora horiza }\end{array}$ \\
\hline S3 & $\begin{array}{l}51 \\
51 \\
50 \\
47 \\
44\end{array}$ & $\begin{array}{l}14,4 \\
15,0 \\
14,9 \\
14,4 \\
14,4\end{array}$ & $\begin{array}{l}\text { (II), III, } \\
\text { IV, V, VI }\end{array}$ & $\begin{array}{l}\text { Phaeophyscia hirsuta } \\
\text { Arthonia melanophthalma } \\
\text { Lecanora hybocarpa } \\
\text { Porina aenea } \\
\text { Thelopsis isiaca }\end{array}$ \\
\hline S4 & $\begin{array}{l}41 \\
34\end{array}$ & $\begin{array}{l}16,0 \\
16,0\end{array}$ & $\begin{array}{l}\text { (III), IV } \\
\text { V, VI }\end{array}$ & $\begin{array}{l}\text { Schismatomma decolorans } \\
\text { Lecidella elaeochroma }\end{array}$ \\
\hline S5 & $\begin{array}{l}21 \\
21\end{array}$ & $\begin{array}{l}16,8 \\
17,4\end{array}$ & $\begin{array}{l}\text { (III, IV), V } \\
\text { VI }\end{array}$ & $\begin{array}{l}\text { Pertusaria heterochroa } \\
\text { Physcia gr. tenella }\end{array}$ \\
\hline
\end{tabular}

Taula 2.- Grups de sensibilitat de les espècies (S1-S5) definits a partir de la Presència total (P2), de l'Index ecològic (Q2) i de la Repartició (en números romans, zones on l'espècie és present; entre parèntesis, zona on l'espècie és present, com a màxim, en un $50 \%$ de les estacions).

presenten recobriments més baixos respecte de la zona superior. El nombre mitjà d'espècies i la riquesa florística mitjana per zona, reflecteixen, en canvi, que existeix un increment d'ambdós paràmetres en passar d'una zona a l'altra. 
La zona II presenta una mitjana de $7 \mu \mathrm{g} / \mathrm{m}^{3}$ de $\mathrm{SO}_{2}$ i $13,4 \mu \mathrm{g} / \mathrm{m}^{3}$ de fums. Segons les dades dels sensors només una part de la zona I, corresponent a les ciutats de Tarragona i Valls, presenta un contingut més elevat de $\mathrm{SO}_{2}$ i de fums que la zona II $\left(23,13 \mu \mathrm{g} / \mathrm{m}^{3} \mathrm{de}\right.$ $\mathrm{SO}_{2}$ i $22,3 \mu \mathrm{g} / \mathrm{m}^{3}$ de fums). La resta de la zona I, corresponent als polígons industrials de Tarragona, està caracteritzada pels mateixos valors de $\mathrm{SO}_{2}$ i fums que la zona II.

D'acord amb les dades preexistents de contaminants atmosfèrics $\left(18 \mu \mathrm{g} / \mathrm{m}^{3}\right.$ de $\mathrm{SO}_{2} \mathrm{i}$ $94 \mu \mathrm{g} / \mathrm{m}^{3}$ de fums); els valors de l'IPA i del RMG de l'estació E56 (caracteritzada per presentar uns valors intermedis entre les zones II i III per ambdós paràmetres); i la dispersió teòricament centrífuga dels contaminants, hem cartografiat l'àrea corresponent a la ciutat de Valls i als seus voltants (sense estacions disponibles per l'absència de garrofers), tal i com s'observa a la figura 1. La disposició teòrica d'aquestes corbes s'expressa mitjançant una línia discontínua.

La zona I inclou 4 estacions situades prop de la ciutat de Tarragona i en plena zona industrial. Totes les estacions presenten líquens. El nombre màxim d'espècies és de 3 per estació i la llista d'espècies de la zona és de 4 . Remarquem la presència de Dirina ceratoniae a totes les estacions, més o menys ben desenvolupada. Segons les dades oficials sobre continguts de l'aire en contaminants, la ciutat de Valls queda inclosa també en aquesta zona I.

La zona II inclou 18 estacions situades al voltant de les ciutats de Tarragona i Reus i dels polígons industrials de Tarragona i de la conca del Francolí. El canvi de la vegetació liquènica respecte a la zona I és brusc per a tots els paràmetres. S'observa la presència constant de 7 espècies i la llista d'espècies de la zona és ja de 14. L'estació intermèdia, E56, situada $2 \mathrm{~km}$ al sud de la ciutat de Valls, presenta, pel fet de trobar-se a la zona que hem anomenat de "transició", 4 espècies pròpies del Lecanoro hybocarpae-Caloplacetum pollinii que no apareixen mai a les estacions de la zona II situades en el domini del Dirinetum ceratoniae. Aquestes espècies són les úniques responsables de l'increment de l'IPA, que assoleix valors intermedis entre els de les zones II i III. La resta d'espècies presents en aquesta estació pertany al domini del Dirinetum ceratoniae, i té valors de presència i de recobriment més pròxims als que presenten les mateixes espècies a la zona II que els que tenen a la zona III.

La zona III, inclou 18 estacions. Totes envolten la zona II i se situen més o menys allunyades de la influència immediata dels focus contaminants. El canvi de la vegetació respecte a la zona II també és brusc per a tots els paràmetres. Es constata la presència constant de 12 espècies i la llista d'espècies de la zona és de 23 . Totes les espècies presents a la zona anterior presenten en aquesta zona freqüències més altes. La inflexió de la corba d'isocontaminació que separa, al nord de l'àrea estudiada, les zones II i III, es deu gairebé amb tota seguretat al vent dominant en aquesta zona, el mestral. La direcció NW d'aquest vent coincideix amb la disposició d'aquesta corba. L'estació intermèdia E26 presenta per els dos paràmetres considerats valors clarament intermedis entre les zones III i IV. Es troba situada a la vora de la localitat litoral més interessant de la província de Tarragona: La Punta de La Mora (GIRALT et al., 1991). Els valors de l'IPA i del RMG demostren que aquesta localitat excepcional està sotmesa a la influència de la contaminació. Malhauradament doncs, cal afegir aquest factor a d'altres d'origen antròpic que amenacen el seu equilibri ecològic.

La zona IV inclou 15 estacions, de les quals 3 es troben en el domini del LecanoroCaloplacetum i s'han exclòs en el càlcul de l'IPA2. Totes envolten, excepte l'estació E18, la zona III. El canvi de la vegetació liquènica respecte a la zona anterior és també brusc per a tots els paràmetres. Només dues espècies més s'incorporen a la llista d'espècies constants, però la llista d'espècies de la zona és ara de 35 . Totes les espècies presents a la 
zona anterior presenten en aquesta zona freqüències més altes. L'estació E18 queda inclosa a l'interior de la zona V. Els valors més baixos tant de l'IPA com del RMG respecte a les estacions de la zona $\mathrm{V}$ és deuen possiblement a què es troba situada sota l'influència immediata de la fàbrica Pirelli, a Torredembarra.

La zona V inclou 23 estacions (7 situades en el domini del Lecanoro-Caloplacetum). Totes envolten la zona IV. El canvi de la vegetació liquènica respecte a la zona anterior no és tant brusc com fins ara. La llista d'espècies de la zona es de 39. L'increment de l'IPA respecte a la zona anterior es deu més a l'increment del recobriment de les espècies que ja trobavem a la zona III que a l'aparició d'espècies noves, totes amb freqüències molt baixes.

La zona VI inclou 5 estacions, totes situades a la zona de "transició". En aquest cas, l'augment de l'IPA respecte a la zona anterior es deu més a l'increment en el nombre d'espècies de cadascuna de les estacions que la integren, (totes tenen entre 19 i 23 espècies), que a un augment del recobriment $\mathrm{i}$ de la presència de les espècies que ja trobavem a la zona V. Aquesta zona queda inclosa a l'interior de la zona V, envoltada, al nord, per estacions que pertanyen al domini del Lecanoro hybocarpae-Caloplacetum pollinii i, al sud, per estacions que pertànyen al del Dirinetum ceratoniae.

L'ordenació de les estacions a la taula 3 es correspon amb la seva inclusió a les zones d'isocontaminació. Totes les que pertanyen a una mateixa zona estan agrupades. Les estacions intermèdies es presenten també correctament situades. L'ordenació de les estacions a la taula a partir del RMG creixent només provoca permutacions entre les estacions d'una mateixa zona. En canvi, l'ordenació en funció del nombre d'espècies barreja les estacions de les zones III, IV i V, de manera que no és possible visualitzar les diferents zones d'isocontaminació a la taula.

\section{Classes de sensibilitat}

La classificació de les espècies a la taula 3 segons el valors decreixents de P2 és coherent amb la seva inclusió a les classes de sensibilitat definides amb altres criteris (taula 2). Les espècies de classes diferents no es barrejen, excepte Bactrospora patellarioides. En canvi, l'ordenació de les espècies a la taula 3 en funció del valor decreixent de PT, no és tant coherent. Tres espècies de la classe de sensibilitat S2 (Hyperphyscia adglutinata, Xanthoria parietina i Lecanora horiza) es barrejen amb les espècies de la classe $\mathrm{S} 1$ (excepte Pleurococcus). Això s'explica perquè les espècies de la classe S2, totes força cosmopolites, apareixen a les 10 estacions del domini del Lecanoro-Caloplacetum, mentre que les de la classe S1, de l'associació Dirinetum ceratoniae, hi són absents. Com a conseqüència, en incloure aquestes 10 estacions, la presència total (PT) s'incrementa només en el cas de les espècies de la classe S2.

L'índex ecològic Q2 (que exclou 10 estacions del domini del Lecanoro hybocarpaeCaloplacetum pollinii) no varia en les espècies del Dirinetum ceratoniae, mentre que s'incrementa en les espècies del Lecanoro hybocarpae-Caloplacetum pollinii, respecte de l'index ecològic QT.

L'assignació de les espècies a les diferents classes de sensibilitat mereix ésser comentada: Entre les de la classe S1 destaca Schismatomma picconianum. L'hem situada en aquesta classe a causa de la seva presència en una de les quatre estacions de la zona d'isocontaminació I. Convé remarcar que la seva presència total (P2) i el seu índex ecològic (Q2), són intermedis entre les classes S1 i S2. Es doncs lleugerament més sensible que les altres espècies de la mateixa classe. El seu comportament a les altres zones d'isocontaminació és idèntic al que presenten altres espècies de la mateixa classe. Entre les de la classe S2 Lecanora horiza és lleugerament més sensible que les espècies de la 
mateixa classe. A la classe S3 observem tres tipus de comportament diferents. Phaeophyscia hirsuta, Porina aenea i Thelopsis isiaca augmenten paulatinament la seva presència des de la zona II fins a la zona V. A partir d'aquesta es presenten constantment (en un $100 \%$ de les estacions). Arthonia melanophthlama augmenta paulatinament la seva presència des de la zona II fins a la zona IV. A partir d'aquesta la trobem ja en un $100 \%$ de les estacions. Finalment, Lecanora hybocarpa és l'única de la classe que no apareix en cap estació de la zona II però, en canvi, és present a partir de la zona III a totes les estacions. Entre les espècies de la classe S4, Lecidella elaeochroma augmenta paulatinament de la zona III fins a la VI. Fins a la zona menys contaminada no assoleix valors màxims de presència (100\%), mentre que Schismatomma decolorans apareix en un $100 \%$ de les estacions a partir ja de la zona IV. Pertusaria heterochroa i Physcia gr. tenella, de la classe S5, es comporten d'igual manera. La seva presència augmenta progressivament des de la zona III, on apareixen en un $10 \%$ de les estacions, fins a la zona VI, on apareixen en un $80-100 \%$ de les estacions.

Les classes de sensibilitat resultants demostren que les espècies del Dirinetum ceratoniae, millor adaptades ecològicament, són, en general, més resistents a la contaminació atmosfèrica que les espècies del Lecanoro hybocarpae-Caloplacetum pollinii. Hem observat, però, que en estacions de les zones II i III (sotmeses a la influència de la contaminació) situades a la zona de "transició", on ambdues comunitats conviuen, les espècies del Dirinetum ceratoniae esdevenen més sensibles mentre que les del LecanoroCaloplacetum, esdevenen més resistents. L'increment de resistència a la contaminació que experimenten les espècies d'aquesta última associació quan es troben en el seu hàbitat òptim, coincideix amb els resultats obtinguts per altres autors (HAWKSWORTH \& ROSE, 1970; RodA, 1979; GonZAlez Bueno, 1986). Així, per exemple, segons aquests autors, Lecidella elaeochroma es mostra, en llocs de clima mediterrani no tant tèrmics (Sabadell i Madrid), com una espècie resistent.

\section{CONCLUSIONS}

Hem distingit cinc zones d'isocontaminació (I-V), que se situen de manera concèntrica al voltant de les ciutats de Tarragona, Reus i Valls i dels polígons de Tarragona i del Francolí. Una sisena zona (VI) ha estat definida, inclosa a la zona V. La seva situació i vegetació liquènica semblen indicar que els seus valors més elevats de l'IPA, del RMG i del nombre d'espècies, es deuen a factors no directament relacionats amb la puresa atmosfèrica.

La majoria de les espècies trobades són crustàcies i pertanyen a dues associacions: Dirinetum ceratoniae i Lecanoro hybocarpae-Caloplacetum pollinii. La resistència als contaminants atmosfèrics considerats sembla relacionada amb la seva adaptació ecològica.

Quinze espècies i una alga epifítica han estat repartides en cinc classes de sensibilitat a la contaminació. Cinc espècies més mostren pautes de comportament que poden ser atribuïdes a la contaminació: Opegrapha varia, Catillaria nigroclavata, Caloplaca pollinii, Opegrapha niveoatra i Dirina ceratoniae f. sorediata. La resposta a la contaminació no és la mateixa en cada una de les espècies d'una mateixa classe de sensibilitat. Algunes augmenten la seva freqüència paulatinament en passar d'una zona a l'altra; d'altres, a partir del seu límit suportable, presenten ja freqüències màximes.

El mapa representat a la figura 1 indica que els nivells alts de contaminació es troben localitzats a les zones I i II. Suggereix també que la influència de la contaminació es fa 


\begin{tabular}{|c|c|c|c|c|c|c|c|c|c|c|c|c|}
\hline \multirow[b]{2}{*}{ Número de l'estació } & \multicolumn{5}{|c|}{$\mathrm{P}$ aràmetres } & \multicolumn{4}{|c|}{ Zona I } & \multicolumn{2}{|c|}{ Zona } & \multirow{2}{*}{$\begin{array}{c}\text { I I } \\
\text { E14 }\end{array}$} \\
\hline & & & & & & E1 & E2 & E11 & E8 & E15 & E80 & \\
\hline Nombre d'arbres per estació & & & & & & 5 & 5 & 8 & 8 & 7 & 7 & 6 \\
\hline Nombre d'espècies & & & & & & 2 & 3 & 3 & 3 & 8 & 9 & 10 \\
\hline Diversitat (\%) & & & & & & 9 & 13 & 13 & 13 & 35 & 39 & 43 \\
\hline & $\mathrm{S}$ & Q2 & $\mathrm{P} 2$ & Qt & $\mathrm{Pt}$ & & & & & & & \\
\hline Dirina ceratoniae & 1 & 12,70 & 73 & 12,70 & 73 & 0,60 & 1,30 & 1,13 & 1,25 & 1,29 & 1,29 & 1,42 \\
\hline Pleurococcus sp. & 1 & 12,70 & 72 & 12,70 & 80 & 0,80 & 0,40 & 0,50 & & 0,43 & 0,29 & 0,50 \\
\hline Schismatomma picconianum & 1 & 13,10 & 71 & 13,00 & 74 & . & . & . & 0,63 & 0,57 & 0,57 & 0,33 \\
\hline Hyperphyscia adglutinata & 2 & 13,30 & 70 & 13,10 & 80 & . & . & . & . & 0,14 & 0,43 & 0,33 \\
\hline Xanthoria parietina & 2 & 13,40 & 70 & 13,30 & 80 & . & . & . & . & 0,14 & 0,14 & 0,17 \\
\hline Bactrospora patellarioides & 1 & 12,90 & 69 & 12,90 & 69 & . & 0,40 & 0,63 & 0,75 & 0,71 & 0,71 & 0,83 \\
\hline Lecanora horiza & 2 & 13,60 & 66 & 13,60 & 73 & . & . & . & . & . & 0,29 & · \\
\hline Phaeophyscia hirsuta & 3 & 14,60 & 51 & 14,40 & 57 & . & . & . & . & . & . & \\
\hline Arthonia melanophthalma & 3 & 15,00 & 51 & 15,00 & 51 & . & . & . & . & 0,14 & . & 0,17 \\
\hline Lecanora hybocarpa & 3 & 14,90 & 50 & 14,50 & 60 & . & . & . & . & . & . & \\
\hline Porina aenea & 3 & 14,40 & 47 & 14,40 & 47 & . & . & . & . & . & & 0,17 \\
\hline Thelopsis isiaca & 3 & 14,40 & 44 & 14,40 & 44 & . & . & . & . & . & 0,29 & 0,17 \\
\hline Schismatomma decolorans & 4 & 16,00 & 41 & 16,00 & 41 & . & . & . & . & . & . & . \\
\hline Lecidella elaeochroma & 4 & 16,00 & 34 & 15,20 & 44 & . & . & . & . & . & $\therefore$ & . \\
\hline Opegrapha varia & . & 14,20 & 26 & 14,20 & 29 & . & . & . & . & . & 0,14 & . \\
\hline Catillaria nigroclavata & . & 16,60 & 21 & 15,70 & 29 & . & . & . & . & . & . & . \\
\hline Pertusaria heterochroa & 5 & 16,80 & 21 & 16,80 & 21 & . & . & . & . & . & . & . \\
\hline Physcia tenella gr. & 5 & 17,40 & 21 & 16,30 & 28 & . & . & . & . & & . & \\
\hline Dirina ce. f. sorediata & . & 11,80 & 16 & 11,80 & 16 & . & . & . & . & 0,43 & . & 0,33 \\
\hline Bacidia subfuscae & . & 17,30 & 16 & 17,30 & 16 & . & . & . & . & $\cdot$ & . & $\cdot$ \\
\hline Arthropyrenia punctiformis & . & 16,00 & 15 & 15,80 & 16 & . & . & . & . & . & . & . \\
\hline Caloplaca pollinii & . & 16,40 & 14 & 14,80 & 24 & . & . & . & . & . & . & . \\
\hline Opegrapha niveoatra & . & 17,40 & 14 & 17,40 & 14 & . & . & . & . & . & . & . \\
\hline Caloplaca holocarpa gr. & & 16,90 & 11 & 15,50 & 17 & . & . & . & . & . & . & . \\
\hline Physcia clementei & . & 18,50 & 11 & 18,10 & 12 & . & . & . & . & . & . & . \\
\hline Lecanora chlarotera gr. & . & 17,10 & 9 & 16,60 & 12 & . & . & . & . & . & . & . \\
\hline Xanthoria candelaria & . & 16,40 & 5 & 16,00 & 6 & . & . & . & . & . & . & . \\
\hline Arthothelium sardoum & . & 16,00 & 3 & 13,60 & 13 & . & . & . & . & . & . & . \\
\hline Gyalecta liguriensis & . & 20,60 & 3 & 20,60 & 3 & . & . & . & . & . & . & . \\
\hline Thelenella modesta & . & 18,00 & 2 & 16,00 & 5 & . & . & . & . & . & . & . \\
\hline Caloplaca pulchrevirens & . & 19,50 & 2 & 19,50 & 2 & . & . & . & . & . & . & . \\
\hline Caloplaca quercina & . & 20,00 & 2 & 20,00 & 2 & . & . & . & . & . & . & . \\
\hline Rinodina pyrina & . & 17,00 & 1 & 14,00 & 6 & . & . & . & . & . & . & . \\
\hline Bacidina naegelii & . & 22,00 & 1 & 15,20 & 5 & . & . & . & . & . & . & . \\
\hline Parmelia soredians & . & · & . & 15,00 & 1 & . & . & . & . & . & . & . \\
\hline Buellia punctat & . & . & . & 15,00 & 1 & . & . & . & . & . & . & . \\
\hline Phaeophyscia orbicularis & . & . & . & 15,00 & 1 & . & . & . & . & . & . & . \\
\hline Physcia stellaris & . & . & . & 15,00 & 2 & . & . & . & . & . & . & . \\
\hline Physcia aipolia & . & . & . & 14,50 & 1 & . & . & . & . & . & . & . \\
\hline Ramalina sp. & . & . & . & 11,00 & 1 & . & . & . & . & . & . & . \\
\hline Lecanora strobilinoides & . & . & . & 18,50 & 2 & . & . & . & . & . & . & . \\
\hline Lecanora conizella & $\cdot$ & . & . & 22,00 & 1 & . & . & . & . & . & . & . \\
\hline RMG & & & & & & 1,40 & 2,40 & 2,38 & 2,88 & 4,14 & 4,42 & 4,83 \\
\hline IPAt & & & & & & 1,78 & 2,68 & 2,87 & 3,37 & 4,94 & 5,41 & 5,72 \\
\hline IPA2 & & & & & & 1,78 & 2,68 & 2,87 & 3,37 & 4,95 & 5,43 & 5,74 \\
\hline
\end{tabular}

Taula 3.- Taula de les dades i paràmetres que caracteritzen les estacions (E) i les espècies. D: Diversitat; IPA (IPAT i IPA2): Index de Puresa Atmosfèrica; RMG: Recubriment Mitjà Global; S: Classes de Sensibilitat; P (PT i P2) Presència Total; Q (QT i Q2) Index Ecològic. A l'intersecció, el coeficient F = Freqüència de l'espècie a l'estació. 


\begin{tabular}{|c|c|c|c|c|c|c|c|c|c|c|c|c|c|c|c|c|c|}
\hline & & & & & & $\mathrm{Zo}$ & $\mathrm{n} \mathrm{a}$ & I I & & & & & & & I & & \\
\hline E57 & E81 & E10 & E53 & E51 & E30 & E28 & E29 & E3 & E17 & E50 & E52 & E79 & E77 & E78 & E56 & E25 & E48 \\
\hline 5 & 5 & 8 & 5 & 5 & 5 & 8 & 7 & 9 & 8 & 5 & 5 & 5 & 6 & 5 & 5 & 9 & 5 \\
\hline 7 & 7 & 11 & 9 & 7 & 9 & 13 & 10 & 11 & 9 & 10 & 11 & 10 & 11 & 10 & 11 & 15 & 9 \\
\hline 30 & 30 & 47 & 39 & 30 & 39 & 57 & 43 & 47 & 39 & 43 & 47 & 43 & 47 & 43 & 47 & 65 & 39 \\
\hline 1,20 & 1,20 & 1,38 & 0,40 & $1 ; 10$ & 1,40 & 1,56 & 1,79 & 1,39 & 1,44 & 1,20 & 0,90 & 0,80 & 0,75 & 1,00 & 0,20 & 2,33 & 0,70 \\
\hline 0,40 & 0,80 & 0,38 & 0,80 & 0,80 & 0,60 & 0,25 & 0,57 & 0,56 & 0,75 & 0,20 & 0,40 & 0,20 & 0,50 & 0,40 & 1,00 & 0,44 & 0,80 \\
\hline 1,00 & 0,80 & 0,63 & 0,50 & 1,00 & 0,60 & 0,50 & 0,50 & 0,56 & 0,75 & 0,90 & 1,00 & 0,70 & 0,83 & 1,20 & 0,70 & 0,78 & 1,20 \\
\hline 0,80 & 1,00 & 0,25 & 0,40 & 0,40 & 0,40 & 0,38 & & 0,33 & 0,25 & 0,40 & 0,40 & 0,70 & 1,00 & 0,60 & 0,40 & 0,22 & 0,90 \\
\hline 0,40 & 0,20 & 0,13 & 0,60 & 0,60 & 0,40 & 0,13 & 0,14 & 0,11 & 0,25 & 0,40 & 0,20 & 0,70 & 0,67 & 0,40 & 0,90 & 0,33 & 0,80 \\
\hline . & & 0,75 & & 0,60 & 0,80 & 0,63 & 0,86 & 0,67 & 0,75 & 0,60 & 0,80 & 0,80 & 0,67 & 0,80 & & 0,89 & 0,60 \\
\hline & 0,40 & . & 1,00 & . & 0,20 & 0,38 & 0,29 & 0,33 & 0,25 & 0,60 & 0,60 & 1,10 & 0,83 & 0,80 & 0,80 & 0,33 & 1,20 \\
\hline 0,20 & 0,20 & & 0,20 & . & 0,20 & & & . & . & 0,20 & 0,20 & 0,20 & 0,17 & . & 0,20 & 0,11 & 0,40 \\
\hline . & . & 0,13 & . & . & 0,20 & 0,25 & 0,14 & . & . & . & . & . & 0,17 & . & & 0,39 & \\
\hline . & . & & & & . & & & & & . & & & . & . & 0,90 & 0,11 & 0,60 \\
\hline & . & 0,25 & 0,40 & 0,20 & . & 0,25 & 0,14 & 0,22 & 0,13 & & 0,40 & 0,20 & . & & . & 0,22 & . \\
\hline 0,40 & . & 0,13 & . & . & . & 0,13 & 0,14 & 0,33 & . & 0,40 & . & 0,20 & . & 0,40 & . & 0,22 & . \\
\hline . & . & . & . & . & . & . & . & . & . & . & . & . & . & . & & 0,22 & . \\
\hline . & . & . & . & . & . & . & . & & . & . & . & . & & & 0,40 & . & . \\
\hline . & . & 0,13 & . & . & . & 0,13 & . & 0,33 & . & . & 0,40 & . & 0,17 & 0,20 & . & . & . \\
\hline . & . & . & . & . & . & . & . & . & . & 0,20 & . & . & 0,17 & . & . & & . \\
\hline . & . & . & . & . & . & . & . & . & . & . & . & . & . & . & . & 0,22 & . \\
\hline . & . & & . & . & . & & & & & . & & . & . & . & . & & . \\
\hline . & . & 0,50 & . & . & . & 0,13 & 0,43 & 0,11 & 0,50 & . & 0,20 & . & . & . & . & 0,22 & . \\
\hline . & . & $\cdot$ & & . & . & & . & . & . & . & . & . & . & . & . & . & . \\
\hline . & . & . & 0,20 & . & . & 0,13 & . & . & . & . & . & . & . & . & . & . & . \\
\hline . & . & . & $\cdot$ & . & . & $\cdot$ & . & . & . & . & . & . & . & . & . & . & . \\
\hline . & . & . & . & . & . & . & . & . & . & . & . & . & . & . & . & . & . \\
\hline . & . & . & . & . & . & . & . & . & . & . & . & . & . & . & . & . & . \\
\hline . & . & . & . & . & . & . & . & . & . & . & . & . & . & . & & . & . \\
\hline . & . & . & . & . & . & . & . & . & . & . & . & . & . & & 0,20 & . & . \\
\hline . & . & . & . & . & . & . & . & . & . & . & . & . & . & 0,20 & & . & . \\
\hline . & . & . & . & . & . & . & . & . & . & . & . & . & & . & 0,40 & . & . \\
\hline . & . & . & . & . & . & . & . & . & . & . & . & . & . & . & . & . & . \\
\hline . & . & . & . & . & . & . & . & . & . & . & . & . & . & . & . & . & . \\
\hline . & . & . & . & . & . & . & . & . & . & . & . & . & . & . & . & . & . \\
\hline . & . & . & . & . & . & . & . & . & . & . & . & . & . & . & . & . & . \\
\hline . & . & . & . & . & . & . & . & . & . & . & . & . & . & . & . & . & . \\
\hline . & . & . & . & . & . & . & . & . & . & . & . & . & . & . & . & . & . \\
\hline . & . & . & . & . & . & . & . & . & . & . & . & . & . & . & . & . & . \\
\hline . & . & . & . & . & . & . & . & . & . & . & . & . & . & . & . & . & . \\
\hline . & . & . & . & . & . & . & . & . & . & . & . & . & . & . & . & . & . \\
\hline . & . & . & . & . & . & . & . & . & . & . & . & . & . & . & . & . & . \\
\hline . & . & . & . & . & . & . & . & . & . & . & . & . & . & . & . & . & . \\
\hline . & . & . & . & . & . & . & . & . & . & . & . & . & . & . & . & . & . \\
\hline . & . & . & . & . & . & . & . & . & . & . & . & . & . & . & . & . & . \\
\hline . & . & . & . & . & . & . & . & . & . & . & . & $\cdot$ & . & . & . & . & $\cdot$ \\
\hline 4,80 & 5,00 & 5,00 & 4,60 & 5,00 & 5,20 & 5,38 & 5,86 & 5,56 & 5,50 & 5,40 & 5,80 & 6,00 & 6,00 & 6,20 & 6,40 & 8,44 & 7,80 \\
\hline 5,78 & 5,98 & 5,99 & 6,04 & 6,10 & 6,26 & 6,36 & 6,46 & 6,49 & 6,49 & 6,76 & 7,27 & 7,42 & 7,85 & 7,96 & 8,32 & 9,41 & 9,56 \\
\hline 5,81 & 6,02 & 6,00 & 6,06 & 6,12 & 6,30 & 6,38 & 6,47 & 6,51 & 6,51 & 6,82 & 7,28 & 7,45 & 7,90 & 7,99 & 8,51 & 9,43 & 9,63 \\
\hline
\end{tabular}




\section{Zona III}

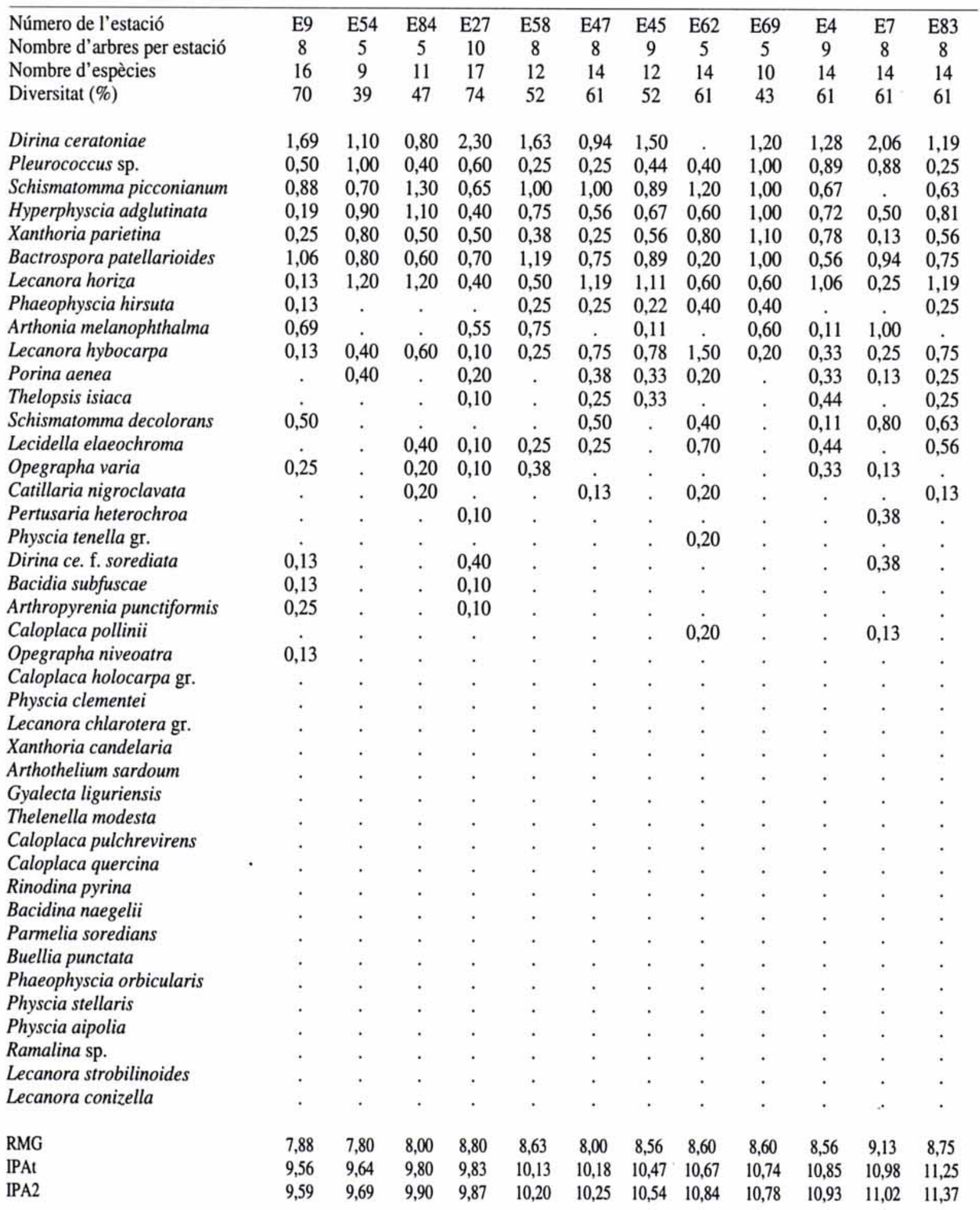

Taula 3 (continuació) 


\begin{tabular}{|c|c|c|c|c|c|c|c|c|c|c|c|c|c|c|c|c|c|}
\hline \multicolumn{2}{|c|}{ Zona } & \multicolumn{2}{|c|}{ I I I } & \multirow{2}{*}{$\frac{\text { I }}{\text { E26 }}$} & \multicolumn{13}{|c|}{ Zona IV } \\
\hline E82 & E85 & E16 & E59 & & E23 & E21 & E49 & E46 & E5 & E76 & E73 & E18 & E61 & E70 & E71 & E55 & E6 \\
\hline 5 & 5 & 8 & 10 & 9 & 8 & 7 & 5 & 9 & 5 & 5 & 6 & 8 & 6 & 5 & 5 & 7 & 8 \\
\hline 14 & 10 & 16 & 14 & 15 & 16 & 15 & 15 & 13 & 15 & 15 & 17 & 17 & 15 & 11 & 12 & 19 & 15 \\
\hline 61 & 43 & 70 & 61 & 65 & -70 & 65 & 65 & 60 & 60 & 65 & 74 & 74 & 65 & 47 & 52 & 83 & 65 \\
\hline 1,10 & & 1,19 & 1,25 & 2,56 & 2,81 & 2,50 & 1,30 & 2,00 & 2,60 & & 1,00 & 2,69 & 1,25 & & & 1,14 & 2,19 \\
\hline 0,60 & 0,80 & 0,75 & 0,40 & 0,67 & 0,63 & 0,29 & 0,20 & 0,56 & 0,80 & 0,60 & 0,33 & 0,88 & 0,17 & 0,60 & 0,80 & 0,29 & 0,88 \\
\hline 1,40 & 0,90 & 1,19 & 1,25 & 1,11 & 1,00 & 0,64 & 1,10 & 1,17 & 0,70 & & 1,25 & 0,38 & 1,42 & 1,00 & & 1,29 & 1,00 \\
\hline 0,40 & 1,0 & 0,63 & 0,40 & 0,33 & 0,63 & 0,70 & 1,00 & 0,56 & 0,20 & 0,70 & 0,67 & 0,38 & 0,67 & 1,00 & 1,00 & 0,43 & 0,13 \\
\hline 0,40 & 0,90 & 0,13 & 0,40 & 0,67 & 0,38 & 0,29 & 0,80 & 0,56 & 0,20 & 0,90 & 0,50 & 0,38 & 0,50 & 1,10 & 1,10 & 0,29 & 0,25 \\
\hline 1,0 & 0,2 & 1,00 & 1,15 & 1,06 & 1,00 & 1,14 & 1,30 & 1,11 & 1,20 & & 0,83 & 0,88 & 0,83 & . & & 1,07 & 0,94 \\
\hline 0,60 & 1,30 & 0,63 & 0,60 & 0,56 & 0,44 & 0,43 & 0,40 & 1,11 & 0,70 & 1,40 & 1,00 & 0,50 & 0,67 & & 1,20 & 1,14 & 0,38 \\
\hline 0,40 & 0,40 & & 0,20 & 0,11 & 0,25 & 0,29 & 0,40 & 0,22 & & 0,40 & 0,33 & 0,13 & 0,50 & 0,40 & . & 0,29 & \\
\hline 0,40 & & 0,50 & 0,90 & 0,44 & 1,13 & 1,00 & 0,60 & 0,90 & 1,10 & & 0,50 & 0,88 & 0,75 & & & 0,57 & 1,19 \\
\hline 0,60 & 1,10 & 0,69 & 0,65 & 0,22 & & & 0,40 & 0,72 & 0,40 & 1,70 & 1,25 & & 1,00 & 2,40 & 2,00 & 1,00 & 0,38 \\
\hline 0,40 & . & 0,38 & 0,30 & 0,56 & 0,50 & 0,29 & & . & 0,20 & . & 0,33 & 0,50 & 0,3 & . & . & 0,29 & \\
\hline 0,40 & . & 0,25 & 0,30 & 0,33 & 0,25 & 0,29 & 1,00 & & & . & & 0,13 & 0,3 & . & . & & \\
\hline 0,40 & & 0,50 & 0,50 & 0,33 & . & 0,71 & 0,40 & 0,61 & 0,80 & & 0,58 & 0,88 & 0,92 & & & 0,79 & 1,44 \\
\hline & 0,90 & 0,25 & 0,30 & 0,22 & & . & . & . & 0,20 & 0,90 & 0,33 & . & 0,50 & 1,20 & 1,20 & 0,29 & 0,13 \\
\hline 0,20 & . & 0,13 & . & . & 0,13 & . & & . & . & & 0,25 & . & . & & . & 0,14 & . \\
\hline . & . & . & . & . & . & & 0,20 & . & & 0,20 & . & & . & 0,20 & . & . & \\
\hline . & . & . & . & . & & 0,43 & . & & 0,20 & & . & 0,63 & & & & & 1,06 \\
\hline . & . & $0^{\circ}$ & . & . & 0,13 & . & 0,40 & 0,22 & . & 0,40 & . & & 0,33 & 0,40 & 0,60 & 0,29 & \\
\hline . & . & 0,13 & . & 0,11 & & . & . & . & & . & . & 0,13 & . & . & . & . & 0,13 \\
\hline . & . & & . & . & 0,25 & & . & . & 0,40 & . & . & 0,38 & . & . & . & . & 0,13 \\
\hline . & & 0,13 & . & . & 0,13 & 0,14 & . & . & 0,20 & & & 0,25 & . & & & . & \\
\hline . & 0,70 & . & . & . & . & & . & & . & 1,00 & 0,58 & . & . & 1,20 & 1,00 & . & 0,13 \\
\hline . & . & . & . & . & & 0,43 & & . & . & & . & 0,19 & . & . & & . & . \\
\hline . & . & . & . & . & 0,13 & . & 0,20 & & . & 0,20 & . & . & . & . & 0,20 & & . \\
\hline . & . & . & . & . & . & . & . & 0,11 & . & 0,20 & & . & . & . & . & 0,29 & \\
\hline . & . & . & . & . & . & . & . & . & . & & 0,17 & . & . & . & . & 0,29 & . \\
\hline . & . & . & . & . & . & . & . & . & . & 0,40 & 0,17 & . & . & & & 0,29 & . \\
\hline . & . & . & . & . & . & . & . & . & . & 0,40 & . & . & . & 0,60 & 0,60 & . & . \\
\hline . & . & . & . & . & . & . & . & . & . & . & . & . & . & . & . & & . \\
\hline . & . & . & . & . & . & . & . & . & . & . & . & . & . & . & . & 0,14 & . \\
\hline . & . & . & . & . & . & . & . & . & . & . & . & . & . & . & . & $\cdot$ & . \\
\hline . & . & . & . & . & . & . & . & . & . & . & . & . & . & . & & . & . \\
\hline . & . & . & . & . & . & . & . & . & . & . & . & . & . & . & 0,40 & . & . \\
\hline . & . & . & . & . & . & . & . & . & . & . & . & . & . & . & . & . & . \\
\hline . & . & . & . & . & . & . & . & . & . & . & . & . & . & . & & . & . \\
\hline . & . & . & . & . & . & . & . & . & . & . & . & . & . & . & & . & . \\
\hline . & . & . & . & . & . & . & . & . & . & & . & . & . & & & . & . \\
\hline . & . & . & . & . & . & . & . & . & . & $.0,20$ & . & . & . & . & . & . & . \\
\hline . & . & . & . & . & . & . & . & . & . & . & . & . & . & . & . & & \\
\hline . & . & . & . & . & . & . & . & . & . & . & . & . & . & . & . & 0,20 & . \\
\hline . & . & . & . & . & . & . & . & . & . & . & . & . & . & . & . & . & . \\
\hline . & . & . & . & . & . & . & . & . & . & . & . & . & . & . & . & . & . \\
\hline 8,80 & 9, & 9,00 & 9,3 & 11, & 11,7 & 11,29 & 10,80 & 11,56 & 12,20 & 11,00 & 11,00 & 12,00 & 11,33 & 12,20 & 12,00 & 11,14 & 12,6 \\
\hline 11,26 & 11,29 & 11,48 & 11,78 & 12,41 & 13,20 & 13,32 & 13,34 & 13,50 & 13,70 & 13,78 & 14,02 & 14,17 & 14,19 & 14,27 & 14,51 & 14,53 & \\
\hline 11,32 & 11,57 & 11,55 & 11,85 & 12,46 & 13,26 & 13,35 & 13,45 & 13,59 & 13,75 & . & 14,24 & 14,23 & 14,35 & . & . & 14,72 & 14,6 \\
\hline
\end{tabular}




\begin{tabular}{|c|c|c|c|c|c|c|c|c|c|c|c|c|}
\hline \multicolumn{3}{|c|}{ Zona IV } & \multicolumn{10}{|c|}{ Zona V } \\
\hline Número de l'estació & E44 & E60 & E20 & E75 & E12 & E43 & E22 & E63 & E65 & E74 & E13 & E19 \\
\hline Nombre d'arbres per estació & 5 & 5 & 8 & 5 & 10 & 6 & 9 & 8 & 6 & 5 & 10 & 8 \\
\hline Nombre d'espècies & 20 & 15 & 16 & 8 & 17 & 18 & 17 & 17 & 15 & 15 & 20 & 16 \\
\hline Diversitat (\%) & 87 & 65 & 70 & 35 & 74 & 78 & 74 & 74 & 65 & 65 & 87 & 70 \\
\hline Dirina ceratoniae & 1,70 & 1,30 & 2,50 & & 2,85 & 0,75 & 2,28 & 2,69 & 2,58 & & 2,80 & 2,19 \\
\hline Pleurococcus sp. & 0,40 & 0,40 & 0,75 & 1,00 & 0,60 & 0,67 & 0,67 & 0,25 & 0,33 & 0,80 & 0,50 & 0,88 \\
\hline Schismatomma picconianum & 1,10 & 1,10 & 0,88 & 0,80 & 1,30 & 1,08 & 0,67 & 1,00 & 1,17 & & 0,95 & 0,88 \\
\hline Hyperphyscia adglutinata & 0,80 & 0,60 & 1,00 & 1,20 & 0,60 & 1,17 & 0,56 & 1,00 & 1,00 & 1,00 & 0,80 & 0,50 \\
\hline Xanthoria parietina & 0,40 & 0,40 & 0,50 & 1,30 & 0,40 & 1,17 & 0,44 & 0,25 & 0,67 & 1,20 & 0,60 & 0,38 \\
\hline Bactrospora patellarioides & 0,80 & 1,10 & 1,25 & . & 0,80 & 0,67 & 1,00 & 1,19 & 1,08 & & 0,80 & 1,13 \\
\hline Lecanora horiza & 0,60 & 0,60 & 0,38 & . & 0,85 & 1,33 & 0,56 & 0,75 & 1,00 & 1,50 & 0,70 & 0,75 \\
\hline Phaeophyscia hirsuta & 0,40 & 0,40 & 0,38 & . & 0,30 & 0,83 & 0,33 & 0,25 & 0,50 & . & 0,50 & \\
\hline Arthonia melanophthalma & 0,20 & 1,10 & 1,13 & & 1,05 & 0,17 & 1,06 & 1,19 & 1,17 & & 0,95 & 1,13 \\
\hline Lecanora hybocarpa & 0,60 & 0,80 & 0,38 & 3,00 & 0,30 & 1,17 & 0,44 & 0,50 & 0,83 & 2,40 & 0,40 & 0,63 \\
\hline Porina aenea & 0,40 & 0,40 & 0,25 & . & 0,60 & & . & 0,38 & 0,33 & . & 0,40 & 0,50 \\
\hline Thelopsis isiaca & 0,40 & & & . & 0,40 & 0,50 & & 0,25 & & . & 0,50 & \\
\hline Schismatomma decolorans & 0,60 & 1,00 & 0,88 & & 0,80 & . & 1,17 & 1,00 & 0,75 & & 0,70 & 0,88 \\
\hline Lecidella elaeochroma & 0,40 & 0,40 & 0,25 & 1,80 & . & & . & 0,50 & & 1,10 & 0,40 & 0,38 \\
\hline Opegrapha varia & 0,20 & . & . & . & . & 0,33 & . & . & 0,17 & 0,20 & & \\
\hline Catillaria nigroclavata & 0,20 & 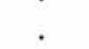 & & . & . & 0,50 & 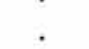 & . & & 0,40 & 0,10 & 0,13 \\
\hline Pertusaria heterochroa & 0,40 & 0,80 & 0,56 & . & & & 0,94 & 0,63 & 0,33 & & & 0,69 \\
\hline Physcia tenella gr. & 0,40 & . & . & . & 0,20 & 0,50 & 0,22 & . & . & 0,60 & 0,20 & . \\
\hline Dirina ce. f. sorediata & . & . & & . & & . & & . & . & . & & . \\
\hline Bacidia subfuscae & . & . & 0,13 & . & 0,70 & . & 0,22 & . & . & . & 0,30 & \\
\hline Arthropyrenia punctiformis & . & & . & & 0,20 & . & 0,39 & & . & & & 0,31 \\
\hline Caloplaca pollinii & . & 0,20 & & 1,70 & . & . & & 0,25 & & 1,00 & 0,10 & \\
\hline Opegrapha niveoatra & & . & 0,63 & . & & & 0,50 & 0,13 & 0,50 & & 0,45 & 0,94 \\
\hline Caloplaca holocarpa gr. & 0,20 & . & . & . & 0,10 & 0,33 & & . & . & 0,20 & . & . \\
\hline Physcia clementei & 0,40 & . & . & . & . & 0,17 & 0,22 & . & . & & . & . \\
\hline Lecanora chlarotera gr. & . & . & . & . & . & . & . & . & . & 0,60 & . & . \\
\hline Xanthoria candelaria & . & . & . & & . & & . & . & & & . & \\
\hline Arthothelium sardoum & . & . & . & 1,00 & . & 0,42 & . & . & . & 0,60 & & . \\
\hline Gyalecta liguriensis & . & . & . & . & . & . & . & . & . & & 0,20 & . \\
\hline Thelenella modesta & . & . & . & . & . & . & . & . & . & 0,20 & . & . \\
\hline Caloplaca pulchrevirens & . & . & . & . & . & . & . & . & . & . & . & . \\
\hline Caloplaca quercina & . & . & . & . & . & & . & . & . & & . & . \\
\hline Rinodina pyrina & . & . & . & . & . & 0,33 & . & . & . & 0,30 & . & . \\
\hline Bacidina naegelii & . & . & . & . & . & . & . & . & . & . & . & . \\
\hline Parmelia soredians & . & . & . & . & . & . & . & . & . & . & . & . \\
\hline Buellia punctata & . & . & . & . & . & . & . & . & . & . & . & \\
\hline Phaeophyscia orbicularis & . & . & . & . & . & . & . & . & . & . & . & . \\
\hline Physcia stellaris & . & . & . & . & . & . & . & . & . & . & . & . \\
\hline Physcia aipolia & . & . & . & . & . & . & . & . & . & . & . & \\
\hline Ramalina sp. & . & . & . & . & . & . & . & . & . & . & . & . \\
\hline Lecanora strobilinoides & . & . & . & . & . & . & . & . & . & . & . & . \\
\hline Lecanora conizella & . & . & . & . & . & . & . & . & . & . & . & . \\
\hline RMG & 10,80 & 11,00 & 13,88 & 15,80 & 14,50 & 13,33 & 13,44 & 14,50 & 14,50 & 14,20 & 14,30 & 14,13 \\
\hline IPAt & 14,94 & 14,95 & 16,52 & 16,57 & 16,75 & 16,75 & 16,77 & 16,99 & 17,20 & 17,35 & 17,35 & 17,41 \\
\hline IPA2 & 15,15 & 15,10 & 16,56 & & 16,84 & 17,18 & 16,86 & 17,13 & 17,24 & & 17,45 & 17,51 \\
\hline
\end{tabular}




\begin{tabular}{|c|c|c|c|c|c|c|c|c|c|c|c|c|c|c|c|c|c|}
\hline \multicolumn{13}{|c|}{ Zona V } & \multicolumn{5}{|c|}{ Zona VI } \\
\hline E64 & E66 & E67 & E31 & E24 & E68 & E72 & E32 & E33 & $\mathrm{E} 42$ & E39 & E37 & E41 & E36 & E35 & E34 & $\mathrm{E} 40$ & E38 \\
\hline 5 & 6 & 5 & 8 & 8 & 8 & 5 & 8 & 7 & 5 & 5 & 5 & 5 & 8 & 6 & 5 & 6 & 7 \\
\hline 14 & 16 & 16 & 23 & 22 & 18 & 18 & 19 & 19 & 16 & 14 & 15 & 14 & 19 & 22 & 23 & 22 & 23 \\
\hline 61 & 70 & 70 & 100 & 96 & 78 & 78 & 83 & 83 & 70 & 61 & 65 & 61 & 83 & 96 & 100 & 100 & 96 \\
\hline 3,00 & 2,42 & 2,10 & 2,75 & 2,38 & 2,31 & & 2,69 & 2,36 & & & & & 2,25 & 1,75 & 2,50 & 1,25 & 0,57 \\
\hline 0,60 & & 0,40 & 0,50 & 1,00 & & 0,60 & 0,13 & 1,00 & 1,00 & 0,60 & 0,80 & 0,80 & 0,63 & 0,33 & 0,40 & 0,33 & 0,43 \\
\hline 1,20 & 0,92 & 1,40 & 0,50 & 0,81 & 1,19 & & 1,25 & 1,64 & 0,50 & & & & 1,25 & 1,58 & 0,80 & 1,25 & 0,71 \\
\hline 0,60 & 0,83 & 1,00 & 1,00 & 0,75 & 0,50 & 0,80 & 1,00 & 1,00 & 1,30 & 1,00 & 1,30 & 1,70 & 0,88 & 1,00 & 1,10 & 0,67 & 1,21 \\
\hline 0,60 & 0,33 & 0,40 & 1,00 & 0,63 & 0,25 & 0,80 & 0,88 & 1,00 & 1,60 & 1,10 & 1,30 & 2,00 & 1,00 & 1,00 & 1,00 & 0,67 & 1,14 \\
\hline 1,40 & 1,08 & & 1,19 & 1,25 & 1,50 & . & 1,00 & 1,57 & & & & & 1,44 & 0,75 & 1,10 & 0,83 & \\
\hline 1,00 & 1,17 & 1,40 & 0,75 & 0,50 & 0,81 & & 0,63 & 0,57 & 1,90 & 2,00 & 1,70 & 2,00 & 0,63 & 0,67 & 0,60 & 1,08 & 1,43 \\
\hline 0,40 & 0,67 & 0,40 & 0,38 & 0,13 & 0,38 & 0,80 & 0,25 & 0,43 & 0,90 & 0,60 & 0,80 & 1,00 & 0,75 & 0,67 & 0,40 & 0,67 & 0,86 \\
\hline 1,20 & 1,08 & 0,60 & 1,25 & 0,75 & 1,13 & & 0,94 & 0,71 & & & & & 1,57 & 1,83 & 1,40 & 1,33 & 0,57 \\
\hline 0,50 & 0,92 & 1,50 & 0,25 & 0,25 & 0,69 & 2,30 & 0,75 & 0,57 & 1,80 & 2,70 & 2,70 & 2,00 & 0,63 & 0,67 & 0,60 & 1,58 & 2,57 \\
\hline 0,40 & 0,50 & 0,40 & 0,13 & 0,50 & 0,88 & $\therefore$ & 0,25 & & . & . & . & . & & 0,33 & 0,40 & 0,33 & 0,29 \\
\hline 0,60 & 0,33 & 0,20 & 0,63 & 0,25 & 0,50 & . & 0,88 & 0,43 & . & . & . & . & 1,13 & 1,08 & 0,80 & 0,50 & 0,29 \\
\hline 1,10 & 0,83 & & 0,38 & 0,75 & 0,75 & & 1,25 & 0,71 & & & & & 1,56 & 1,42 & 1,10 & 1,33 & 0,64 \\
\hline . & 0,67 & 1,00 & 0,13 & 0,25 & 0,50 & 1,20 & 0,25 & 0,14 & 1,20 & 1,30 & 1,40 & 1,00 & 0,38 & 0,17 & 0,30 & 1,00 & 1,21 \\
\hline . & . & & 0,13 & 0,13 & & & . & & 0,20 & & 0,20 & & & 0,17 & & 0,17 & \\
\hline . & . & 0,40 & 0,25 & 0,13 & 0,25 & 0,60 & . & 0,14 & 0,60 & 0,60 & 0,40 & 0,40 & 0,13 & 0,17 & 0,20 & 0,33 & 0,43 \\
\hline . & & & 0,38 & 0,63 & 0,56 & & & & . & & & . & 0,63 & 0,50 & 1,00 & 0,67 & \\
\hline . & 0,33 & 0,40 & 0,13 & . & . & 0,80 & 0,25 & 0,29 & . & 0,90 & 1,00 & . & 0,38 & 0,67 & 0,40 & 0,50 & 1,00 \\
\hline . & $\cdot$ & . & & $0^{\circ}$ & . & . & & & . & . & . & . & $\cdot$ & & & . & . \\
\hline . & . & . & 0,13 & 0,13 & . & . & 0,38 & 0,14 & . & . & . & & & 0,17 & 0,20 & & . \\
\hline . & . & . & 0,13 & 0,25 & & $\therefore$ & & . & & & & $\begin{array}{l}0,40 \\
0,60\end{array}$ & 0,13 & . & & $\begin{array}{l}0,17 \\
0,67\end{array}$ & 0.57 \\
\hline$\cdot$ & . & 0,40 & & & 0,25 & 1,10 & 0,13 & . & 0,60 & 0,40 & 0,60 & 0,60 & 0,13 & 0,33 & $\begin{array}{l}0,20 \\
0,20\end{array}$ & $\begin{array}{c}0,67 \\
.\end{array}$ & 0,57 \\
\hline 0,20 & 0,17 & . & $\begin{array}{l}0,38 \\
0,25\end{array}$ & 1,00 & $\cdot$ & $\cdot$ & $\dot{\cdot}$ & 0,29 & 0,40 & 0,20 & 0,20 & 0,40 & & 0,3 & & 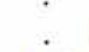 & 0,43 \\
\hline . & & & . & 0,13 & & $\cdot$ &. & 0,29 & . & & . & . & 0,13 & . & 0,40 & 0,50 & 0,36 \\
\hline . & 0.33 & 0,60 & . & 0,13 & 0,25 & 0,90 & . & & . & 0,60 & . & . & . & & . & 0,33 & 0,57 \\
\hline . & . & . & . & . & . & & . & 0,29 & & & & & . & 0,17 & . & . & \\
\hline . & . & . & . & . & . & 0,80 & . & . & 0,60 & 0,90 & 0,60 & 0,80 & . & & & . & 0,43 \\
\hline$\cdot$ & . & . & . & . & . & . & & . & & . & & . & . & 0,17 & 0,20 & . & . \\
\hline . & . & . & & . & & . & 0,13 & . & 0,40 & . & 0,40 & . & . & $\cdot$ & . & . & . \\
\hline . & . & . & 0,13 & . & 0,13 & . & & . & . & . & . & . & . & . & & & . \\
\hline . & . & . & . & . & . & & 0,25 & . & & . & . & Din & . & . & 0,20 & . & . \\
\hline . & . & . & . & . & . & 0,40 & . & . & 0,40 & & & 0,40 & . & . & . & . & \\
\hline . & . & . & . & . & . & & . & . & 0,40 & 0,60 & 0,40 & 0,60 & . & . & . & . & 0,29 \\
\hline$\cdot$ & . & . & . & . & . & 0,20 & . & . & . & . & . & . & . & . & . & . & . \\
\hline$\cdot$ & . & . & . & . & . & 0,20 & . & . & . & . & . & . & . & . & . & . & . \\
\hline . & . & . & . & . & . & 0,40 & . & . & . & . & . & . & & . & & . & . \\
\hline . & . & . & . & . & . & 0,20 & . & . & . & . & . & . & . & . & . & . & . \\
\hline . & . & . & . & . & . & 0,20 & . & . & . & . & . & . & . & . & . & . & $\cdot$ \\
\hline . & . & . & . & . & . & & . & . & . & . & . & . & . & & & . & \\
\hline . & . & . & . & . & . & 0,20 & . & . & . & . & . & . & . & . & . & $\cdot$ & $\begin{array}{l}0,14 \\
0.14\end{array}$ \\
\hline . & . & . & . & . &. & . & . & . & . & . & . & $\cdot$ & . & . & . & . & 0,14 \\
\hline
\end{tabular}

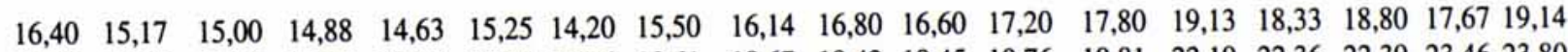

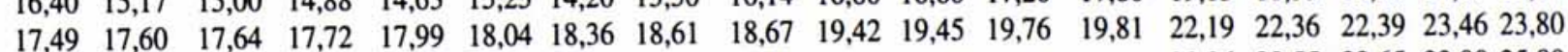

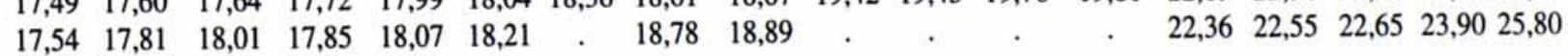


notar fins a una distància aproximada de $15 \mathrm{~km}$ dels focus contaminants, tant cap a llevant com cap a ponent. A partir d'aquesta distància i fins a $25 \mathrm{~km}$ (distància màxima on se situen les estacions més allunyades dels focus contaminants), tots els paràmetres calculats per a definir les zones d'isocontaminació (fig. 2), poc o molt, es mantenen estables, fet que demostra que les estacions situades a aquesta distància dels focus contaminants (entre 15$25 \mathrm{~km}$ ) ja no estan sotmeses a la seva influència.

La comparació entre els resultats obtinguts a GIRALT et al. (1989) i els obtinguts ara, demostra que la contaminació al territori es troba més o menys estabilitzada en alguns punts, mentre que s'ha incrementat en altres punts, a diferència del que indiquen les dades oficials, basades en mesures directes sobre continguts en contaminants de l'aire.

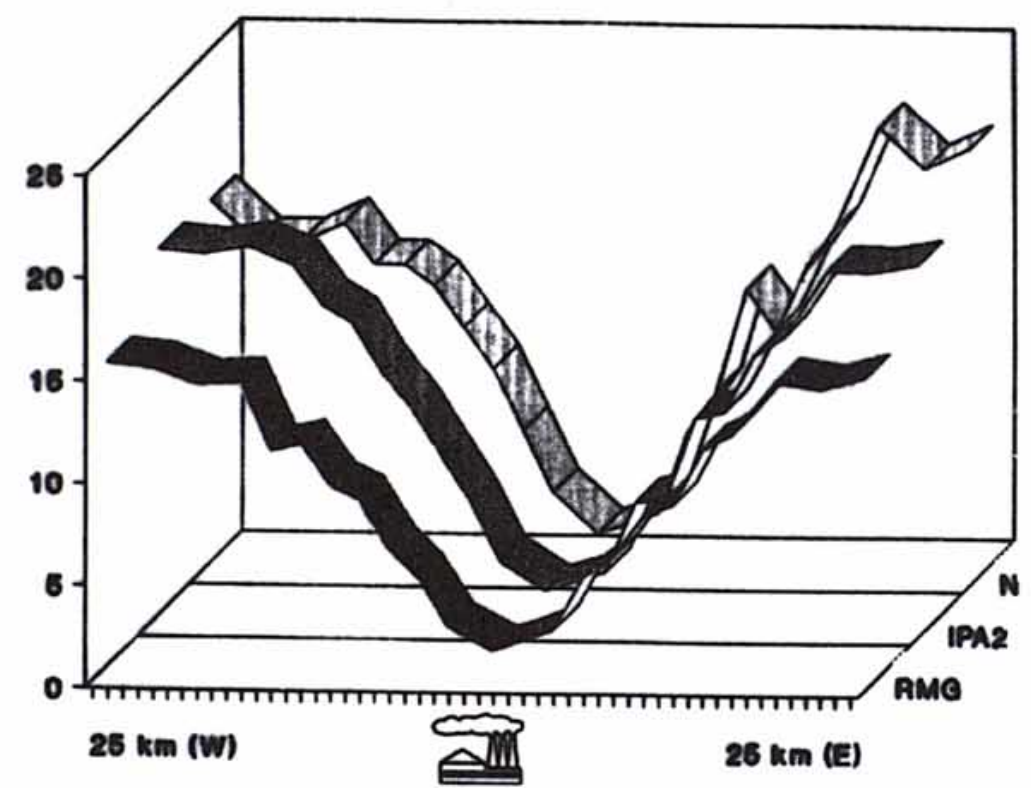

Fig. 4.- Transecte des dels focus contaminants principals (ciutat de Tarragona i polígons) fins a $25 \mathrm{~km}$ a l'est i a l'oest. S'observa com els diferents paràmetres calculats (IPA2, RMG i N) s'incrementen paulatinament fins a una distància aproximada de $25 \mathrm{~km}$ dels focus contaminants i com a partir d'aquesta distància poc o molt s'estabilitzen.

La presència a la zona estudiada de dos ambients diferenciats, als quals corresponen dues comunitats liquèniques distintes, ha obligat a la realització de dos càlculs de l'IPA. Tot i que els resultats obtinguts entre l'un i l'altre són gairebé idèntics (condueixen al mateix mapa d'isocontaminació), les petites variacions observades permeten ratificar que l' 'índex de puresa atmosfèrica de LEBLANC \& DE SLOOVER (1970) ha d'ésser aplicat en condicions homogènies però que una certa heterogeneïtat proporciona, fins i tot, més informació, especialment sobre les exigències ecològiques de les espècies i comunitats, sempre que el coneixement de la flora i de la vegetació liquènica de l'àrea estudiada sigui prou profund.

Es demostra que l'índex de puresa atmosfèrica pot ésser perfectament aplicat en zones de clima mediterrani suau, tot $\mathrm{i}$ que el col.lectiu d'espècies presents en aquestes zones és ben diferent del que habitualment s'ha utilitzat.

Per últim, volem dir que l'avaluació de la qualitat de l'aire és un dels elements fonamentals en qualsevol política de conservació de la natura. Com a resultat del present treball confirmem que aquesta pot ser millorada, si es duu a terme tenint en compte, no només les dades proporcionades pels sensors de contaminants sino els líquens, que, en aquest domini, constitueixen els millors indicadors biològics fins ara coneguts, ja que, ultra llur 
sensibilitat, proporcionen dades d'un gran nombre de punts i, a més, integren les condicions atmosfèriques que han existit durant els darrers anys.

\section{Agraïments}

Voldriem fer constar el nostre agraiment a A. Gómez-Bolea i a X. Llimona, per la revisió del manuscript, i al Sr. O. Puig, Cap del Servei de Protecció de l'Ambient Atmosfèric de la Generalitat de Catalunya, per proporcionart-nos les dades sobre els continguts de l'aire en contaminants.

\section{Bibliografia}

BRIGHTMAN, F. H. (1982). Erasmus Darwin claims the earliest mention of lichens and air pollution (1790). Bull. Br. Lichen Soc. 51: 18.

CASE, J.W. (1980). The influence of three sour gas processing plants on the ecological distribution of epiphytic lichens in the vicinity of Fox Creek and Whitecourt, Alberta, Canada. Water, Air and Soil Pollution 14: 45-68.

Crespo, A., ManRiQue, E., BarReno, E. \& E. SeriÑa (1977). Valoración de la contaminación atmosférica del área urbana de Madrid mediante bioindicadores (líquenes epífitos). Anales Inst. Bot. Cavanilles 34 (1): 71-94.

Crespo, A., Barreno, E., Sancho, L.G. \& A. Gonzalez Bueno (1981). Restablecimiento de una red de pureza atmosférica en la provincia de la Coruña (España) mediante bioindicadores liquénicos. Lazaroa 3: 289-311.

DeRUElle, S. (1983). Écologie des lichens du Bassin Parisien. Impact de la pollution atmosphérique (engrais, $\left.\mathrm{SO}_{2}, \mathrm{~Pb}\right) \&$ relations avec les facteurs climatiques. Thèse Doctorale d'État. Univ. de Paris VI.

DERUELLE, S. \& F. GARCIA-SCHAEFFER (1983). Les liquens bioindicateurs de la pollution atmosphérique dans la région parisienne. Cryptogamie, Bryol. Lichénol. 4 (1): 47-64.

DeRUelle, S. \& R. LALlEMENT (1983). Les liquens témoins de la pollution. Vuibert. Paris.

GIRALT, M. (1986). Flora i vegetació dels líquens epífits del Tarragonès. Aplicació al problema de la contaminació atmosfèrica. Fundació "Antoni i Vicenç Mestres Jané". Vilafranca del Penedès.

GIRALT, M. (1991). Flora i vegetació liquènica epifítica de la plana i serralades litorals tarragonines. Estimació de la contaminació atmosfêrica a la plana del Camp de Tarragona prenent els líquens com a bioindicadors. Tesi Doctoral. Univ. de Barcelona.

GIRALT, M. (1996). Líquens epífits i contaminació atmosfèrica a la plana i les serrelades litorals tarragonines. Institut d'Estudis Catalans. Barcelona.

Giralt, M., Gomez-Bolea, A. \& X. Llimona (1991). Flora liquènica epifítica de la Punta de la Mora (Tarragonès, Catalunya). Butll. Ins. Catalana Hist. Nat. 59: 57-69.

Giralt, M., Letrouit-Galinou, M. A. \& A. Gomez-Bolea (1989). Estimation de la pollution atmosphérique en utilisant les lichens comme bioindicateurs dans le littoral du Tarragonès (Catalogne, Espagne). Cryptogamie, Bryol. Lichénol. 10 (2): 131-146.

Gonzalez Bueno, A. (1986). Valoración de la contaminación atmosférica en el área de influencia de Madrid y corredor industrial del Henares mediante líquenes epífitos. Tesis Doctoral. Univ. Autónoma de Madrid.

GRANGER, J. M. (1972). Computer mapping as an aid in Air Pollution: Montreal region study. Sarracenia 15: 43-83.

KLEMENT, O. (1965). Flechtenflora und Flechtenvegetation der Pityusen. Nova Hedwigia 9: 435-501.

HAWKSWORTH, D. L. \& F. ROSE (1970). Qualitative scale for estimating sulphur dioxid pollution in England and Wales. Nature 227: 145-148.

Leblanc, F. \& De Sloover, J. (1970). Relation between industrialization and the distribution and growth of epiphytic lichens and mosses in Montreal. Can. J. Bot. 48: 1485-1496.

NYLANDER, W., (1866). Les lichens du jardin de Luxembourg. Bull. Soc. Bot. France 13: 364-372.

RODA, F. (1979). Epífitos y contaminación atmosférica en los alrededores de Sabadell (Cataluña). Mediterranea 3: 23-68.

VAN HALUwYN, Ch. \& M. LeROND (1986). Les liquens et la qualité de l'air, évolution méthodologique et limites. Ministère de l'Environnement. S.R.E.T.I.E.: 1-207.

Acceptat: desembre de 1992 